\title{
Tautinio paveldo produktų vertė, rinkodara ir plètros kryptys
}

Vitalija Rudzkienè ${ }^{1}$,

\section{Reda Skrodenyt $\dot{e}^{2}$}

${ }^{1}$ Mykolo Romerio universiteto Verslo ekonomikos katedra, Ateities g. 20, LT-08303 Vilnius

El.paštas:vital@mruni.lt

${ }^{2}$ Lietuvos mokslu akademijos Žemès ūkio ir mišku mokslų skyrius, Gedimino pr. 3, LT-01103 Vilnius

El.paštas: r.skrodenyte@lma.lt
Tautinis paveldas, tradiciniai amatai ir kulinarinis paveldas yra svarbi valstybès etninès kultūros dalis. Tačiau kuriant tautinio paveldo produktų išsaugojimo, populiarinimo ir realizavimo sistemą mažai dèmesio skiriama rinkodaros priemonems. Poreikis rinkodaros strategijai formuoti atsiranda tiek iš amatininko, tiek iš valstybinę apsaugą užtikrinančiu institucijų, tiek iš vartotojo pusès. Tautinio paveldo produktų gamintojams svarbu, kad jų gaminiai turètų paklausą, vartotojai visada domètųsi jais ir pirktų šiuos produktus. O valstybinę apsaugą užtikrinančiu institucijų uždavinys yra užtikrinti tautinio paveldo produktų išsaugojimą, skatinti jų kūrimąsi, plètoti tradicinius amatus. Siekiant igyvendinti šiuos tikslus yra būtinybè pasitelkti priemones, didinančias tautinio paveldo produktų populiarumą ir paklausą.

Mykolo Romerio universitete 2010-2011 m. atliktas trijų tipų empirinis tyrimas, kurio tikslas - išanalizuoti ir empiriškai çvertinti skirtingose vietovèse tautinio paveldo produktų rinką gamintojo ir vartotojo požiūriu. Tikslui pasiekti taikyti: Stjudento $t$ kriterijaus, vienfaktorinès dispersinès analizės (ANOVA), struktūrizuoto interviu ir anketinès apklausos metodai. Tyrimo metu daug dèmesio skiriama tautinio paveldo produktų plètros ir vertès analizei. Tyrimo rezultatai rodo, kad $2011 \mathrm{~m}$. liepos mèn. Lietuvoje buvo sertifikuota 1159 tautinio paveldo produktų, o tradicine amatininkyste užsièmé 353 amatininkai, kurių daugiausiai buvo mažuose miesteliuose ir kaimiškose vietovese. Nustatyta, kad tautinio paveldo produktų gamintojai taiko tradicines (nusistovejusias) rinkodaros priemones, kas lemia mažą tautinio paveldo produktų paklausą. Per maža informacijos sklaida apie sertifikuotus tradicinius gaminius, amatininkus ir vykstančias šventes varžo vartotojų domëjimąsi tradiciniais amatais. Tyrimo rezultatai leido nustatyti alternatyvius sprendimus, kaip didinti tautinio paveldo produktų plètrą ir paklausą. Tai savo veikloje turètų taikyti tautinio paveldo produktų apsaugą užtikrinančios institucijos.

Raktažodžiai: tautinio paveldo produktai, tautinio paveldo produktų vertė, tautinio paveldo produktų plètra, tautinio paveldo produktų rinkodara

\section{IVADAS}

Iš kartos ị kartą perduodamos ir išlaikomos istoriškai susiformavusios tautinio paveldo tradicijos, patirtis ir specialūs igūdžiai palaiko tautos gyvybingumą bei parodo pasauliui valstybès tautinị išskirtinumą. Tautinio paveldo produktų, būdingų konkrečiai kaimo vietovei ar etnografiniam regionui, išsaugojimas ir puoselejjimas yra svarbi tiek miesto, tiek kaimo vietovių ekonominio ir socialinio gyvybingumo bei patrauklumo didinimo priemonè.

Daugelyje pasaulio šalių amatų gamyba ir prekyba tradiciniais gaminiais yra socialinis ir kultūrinis svertas, kurio dèka palaikomas tautiškumas, originalumas ir tapatybès išsaugojimas nuolat kintančiame globaliame pasaulyje. Greta tradicijų išsaugojimo, ši tautinio paveldo veikla teikia ir 
jaučiamą ekonominę naudą: propaguoja turizmo plètrą, kuria darbo vietas, naudoja vietines žaliavas, skatina vartoti sveikus produktus. O kaip teigia Jonas Jasaitis ir Valerija Kriaučiūnienè (2010), kaimiškujų vietovių savitumo išsaugojimas bei kaimo paveldo objektų panaudojimas ekonominei veiklai įvairinti sudaro sąlygas modernaus kaimo modeliui sukurti, išlaikant Lietuvos kaimui būdingus regioninius kraštovaizdžio ir autentiškos kultūros elementus.

Bègant laikui, dėmesys ir pastangos tautinio paveldo veiklai nemažeja. Europos šalys skiria ypač daug demesio tautinio paveldo veiklos organizavimui. Tam taikomi ịvairūs vadybos metodai ir veiklos organizavimo būdai. Pavyzdžiui, Suomijoje sukurtas nacionalinis amatų tinklas - Taito grupė, kurios veiklos sritis - steigti amatų mokyklas vaikams, jaunimui bei suaugusiems, vykdyti mokymus, organizuoti parodas, platinti amatu produkciją, rūpintis medžiagų tiekimu. Suomijoje amatai yra pragyvenimo šaltinis per 30000 amatininkų (Taito group, 2011) arba 559,3 amatininkams, tenkantiems 100000 Suomijos gyventojų. Lietuvoje yra 10,7 tautinio paveldo produktų kūrèjai, tenkantys 100000 Lietuvos gyventojų (Tautinis paveldas, 2011).

Pasak Susan J. Terbio (2008), amatų puoselèjimas yra vienas iš pragyvenimo šaltinių didelei Prancūzijos gyventojų grupei. Patrauklūs Atlanto paplūdimiai bei Pirènų kalnai ištisus metus pritraukia turistų. Jų dẻka amatų prekyba čia ypač klesti.

Mūsų kaimynai lenkai irgi deda daug pastangų, kad išsaugotų savo šalies tapatybę bei kultūros ir meno plètros tradicijas (Tumènas, 2010). Toki jų elgesi motyvuoja ne vien tik racionalios, bet ir moralinès priežastys (Siemieniako ir kt., 2011). Lenkijos regionai, kurie susidarè per ilgus šimtmečius, pasižymi savita kultūra, politika, ekonomika ir regioniniu identitetu. Daugelyje regionų aktyviai veikia vietos bendruomenès, ir to krašto žmonès aktyviai dalyvauja jų veikloje. Skatinama pirmenybę teikti vietos produktams, net jei jų kokybè yra gerokai prastesné nei importuojamų.

Kiek kitokia padètis yra Kinijoje. Kaip teigia Xianghong Feng (2008), turistų poreikius labai sunku suderinti su amatininkų pardavinèjamais produktais. Amatininkai gamina produktus, kurie yra unikalūs ir turi istorinę vertę, o turistų rinkai to nereikia, jiems svarbiausia yra gaminio kaina.
Todèl gaminiai, kurie turi to krašto simboliką ir yra autentiški, skiriami vietos vartotojams, nes jie labiau supranta gaminio tapatumą ir reikšmingumą negu turistai.

Susipažinus su daugiau ar mažiau sèkminga tautinio paveldo veikla norisi rasti atsakymą, koks veiklos organizavimo būdas, kokie kriterijai lemia sẻkmingą amatininkų verslą? Kokie metodai tinkamiausi numatant ir skatinant amatininkų veiklos plètrą, jų segmentus bei amatų centrų kūrimąsi (Burinskienè, Rudzkienė, 2009)? Kaip teigia tyrèjai, svarbiausia yra sutelkti dèmesị $\mathfrak{t}$ pagrindinius metodus, kurie labiausiai pabrěžia amatams būdingas savybes, dominuojantị produktų kiekį ir jų asortimentą, produktų kokybę, unikalumą, vartotojų susidomèjimą bei puikų klientu aptarnavimo lygi. Ne mažiau svarbus ir pačių amatininkų noras puoselèti senąsias tradicijas, demonstruoti asmeninius igūdžius kuriant tradicinius gaminius ir skatinti bei mokyti vartotojus vartoti tradicinius produktus. Vilma Atkočiūnienè, Alvydas Aleksandravičius, Daiva Albrektaitè (2008) teigia, kad amatu gaminių pateikimo strateginiai sprendimai turetur remtis vartotojų poreikių specifika ir dèsningumais, tačiau tradicinių amatų gaminių rèmimas Lietuvoje vykdomas neatsižvelgiant $\mathfrak{i}$ amatų gyvavimo ciklo stadiją, gaminio specifines savybes ir tikslinius segmentus, praktiškai nèra naudojama amatų gaminių reklama, trūksta profesionalaus požiūrio rengiant amatų gaminių katalogus, organizuojant muges, naudojant asmeninio pardavimo būdus. A. Aleksandravičiaus ir Felikso Klupšo (2009) nuomone, viena iš galimybių, kuri sudarytų prielaidas išlaikyti tradicinius amatus bei jų gyvybingumą - tradicinių amatų centrų steigimas. Tačiau J. Jasaičio (2008) atliktas naujų verslo objektų kūrimo nedideliuose miesteliuose ir gyvenvietèse galimybių vertinimas parodè, kad nedideliuose miesteliuose ir gyvenvietėse nėra galimybių kurti turizmo informacijos, istorijos ir kultūros paveldo centrų. Tradicinių amatu centrus tikslingiausia kurti ten, kur apsistoja poilsiautojai, yra vystomas kaimo turizmas (Jasaitis, Kriaučiūnienè, 2010). Anot V. Atkočiūnienès, A. Aleksandravičiaus, D. Albrektaitès (2008), norint, kad vartotojai tinkamai reaguotų $\mathfrak{i}$ amatų gaminius, reikalingas specialus amatų gaminių rèmimo kompleksas ir realizavimo strategija. Rosalind C. Paige ir Mary A. Littrell (2002) atliktas tyrimas atskleidè, kad 
visi amatininkai turèjo susikūrę vienokias ar kitokias rinkodaros strategijas, kas lemė didesni ar mažesni produkcijos pardavimą.

Tyrimo tikslas - išanalizuoti ir empiriškai ịvertinti skirtingose vietovèse tautinio paveldo produktų rinką gamintojo ir vartotojo požiūriu bei apibrèžti veiksnius, didinančius tautinio paveldo produktų vertę ir paklausą.

Tyrimo uždaviniai:

1. Nustatyti tautinio paveldo produktų gamintojų taikomas rinkodaros priemones.

2. Nustatyti tautinio paveldo produktų paklausą.

3. Ivertinti tautinio paveldo produktų pasiskirstymą Lietuvos teritorijoje.

\section{METODAI IR SĄLYGOS}

Tautinio paveldo produktų vertès ir plètros analizè atlikta remiantis tautinio paveldo produktų literatūros šaltinių analize. Buvo analizuojami tautinio paveldo produktų teisès aktai, sertifikavimo sistema ir užsienio autorių vertès koncepcijos.

Trijų tipų empiriniam tyrimui buvo suformuluotos pradinès tyrimo hipotezès:

1. Tautinio paveldo produktų gamintojai taiko tradicines (nusistovejjusias) rinkodaros priemones.

2. Tautinio paveldo produktų paklausa priklauso nuo jų realizavimo vietų.

3. Tautinio paveldo produktų kūrejjų veikla ịvairiose vietovėse natūraliai formuoja amatininkų centrus.

Pradinių hipotezių patikrinimui buvo atlikti tautinio paveldo produktų gamintojų ir vartotojų tyrimai. Gamintojų apklausa buvo vykdoma Vilniuje per Kaziuko mugę ir žemès ūkio parodoje „Ką pasėsi... 2011“. Apklausti 22 respondentai - mugeje ir parodoje dalyvaujantys tautinio paveldo produktų gamintojai.

Siekiant išsiaiškinti žmonių poreikius vartoti tautinio paveldo produktus ir nustatyti, kokia yra šių gaminių paklausa bei vertè, tyrimo hipotezė buvo tikrinama remiantis vartotojų struktūrizuoto interviu bei anketinès apklausos rezultatais. Vartotojai buvo apklausti tautinio paveldo produktu parodose ir mugèse bei interneto portale $w w w . a p k l a u s a . l t$. Vartotojų apklausa buvo vykdoma $2010 \mathrm{~m}$. balandžio ir gegužès mèn. Pagal sudarytą anketą buvo apklausta 150 respondentų.
Trečioji hipotezè buvo tikrinama remiantis tautinio paveldo produktų sertifikavimo statistinių duomenų analize. Analizuota tautinio paveldo produktų gamintojų skaičius skirtingose Lietuvos teritorijose, išskirti Lietuvos miestai pagal gyventojų skaičių ł̇ didžiuosius (daugiau 100000 gyventojų), vidutinius (30 000-100 000 gyventojų) ir mažuosius (5 000-30 000 gyventojų), atskira grupe išskirti Lietuvos rajonai be rajonų centrų, taip pat tautinio paveldo produktų gamintojų skaičius analizuotas probleminèse Lietuvos teritorijose, nacionaliniuose parkuose bei etnografiniuose regionuose. Hipotezès tikrinimui pritaikytas vienfaktorinès dispersinès analizès metodas (ANOVA). Tyrimui buvo taikomas $5 \%$ $(\alpha=0,05)$ reikšmingumo lygmuo. Tikrinama nulinè hipotezè, kad kelių grupių vidurkiai yra lygūs $\mathrm{H}_{0}: \mu_{1}=\mu_{2}=\mu_{3}=\ldots=\mu_{n}$, kur $n-$ tiriamų grupių skaičius. Nulinès hipotezès tikrinimui taikomas $F$ kriterijus. Kai tiriamos dvi grupès, ANOVA metodas sutampa su Stjudento $t$ kriterijumi dvieju grupių vidurkių lygybei tikrinti.

\section{TAUTINIO PAVELDO KURIAMA VERTE்}

Vertės koncepcijos sąvoka, jos dedamųjų dalių ir reikšmès samprata kito priklausomai nuo laikmečio ir vyraujančių ekonominių paradigmų. Vertẻ buvo išskaidyta $\mathfrak{i}$ „vartojimo vertę“ ir „mainų vertę", kurios dažnai nesutampa arba vertẻ yra kaip ribinių kaštų ir ribinès naudos kainų pusiausvyra. Vadybos moksle vertė varijuoja nuo paprasčiausios kainos iki sudètingai sukonstruotų apibrèžimų, tačiau vertès ir kainų skirtumai juose išlieka. Taigi ekonominè vertẻ gali būti išmatuota pinigų kiekiu, kurị individas sutinka mokèti už prekę ar paslaugą arba sutinka priimti kaip kompensaciją už atiduotą prekę ar suteiktą paslaugą. Bendrosios ekonominès vertès atveju yra pripažįstama, kad yra du pagrindiniai vertes komponentai: naudojimo vertè ir nenaudojimo vertè (Freeman, 1993; Neap, Celik, 1999; Brytting, Trollestad, 2000; Bateman, 2002; Haksever ir kt., 2004; Porter, Kramer, 2011). Atidetos alternatyvos verte paprastai yra išskiriama kaip trečias komponentas, kuri galime priskirti kaip naudojimo taip ir nenaudojimo vertei. Gèrybès gali būti naudojamos tiesiogiai, netiesiogiai ar gali turèti vertę, kuri nebūtinai susijusi su naudojimu. Tiesioginio naudojimo vertė siejama su prekèmis ir paslaugomis, kurias žmonès naudoja tiesiogiai. 
Tautinio paveldo produktų vertė yra sukuriama ne tik per tiesioginę vertę ir naudą gamintojui, bet ir per suvokiamą vertę ir naudą tautinio paveldo produktų vartotojui. Tautinio paveldo produktų vertę vartotojui sudaro tiesioginé, netiesioginé, egzistavimo ir palikimo vertès.

Bendroji tautinio paveldo vertè gali būti apibrèžiama kaip funkcija, priklausanti nuo atskirų verčių komponentų:

$$
B V=f\left(v_{1}, v_{2}, . . v_{k}\right) .
$$

Čia $B V$ - yra bendroji verte, o $v_{1}, v_{2}, \ldots v_{k}$, žymi verčių komponentus. Akivaizdu, kad $B V$ yra suminis dydis, o funkcijos (1) išraiška turètų būti tiesinè, tačiau verčių svoriai gali skirtis. Pavyzdžiui, palikimo verte gali turèti didesnị svorị negu, tarkim, tiesioginè vertè. Tuomet BV galima apibrèžti kaip skirtingų verčių sumą su skirtingais svoriais.

$$
B V=\sum_{i}^{k} \lambda_{i} v_{i}-v^{*}
$$

Čia $i$ - žymi verčių komponentą, $k$ - komponentų skaičių, $v_{i}-i$-ojo komponento vertę, $\lambda_{i}-i$-ojo komponento svori, o $v^{*}$ - persidengiančių komponentų verčių sumą, nes skirtingiems komponentams ta pati vertè gali būti priskirta kelis kartus. Pavyzdžiui, unikalumas svarbus beveik visiems vertès komponentams (1 pav.).
Tautinio paveldo produktų gamintojai, puoselèdami ir gamindami tautinio paveldo produktus, gauna ekonominę ir socialinę vertę (2 pav.). Ekonominę vertę sudaro gaunamų pajamų iš pardavimų, valstybès pagalbos bei ES paramos ir patiriamų išlaidų žaliavoms, medžiagoms, tiekimui ir patekimui į rinką, skirtumas. Socialinę vertę sudaro unikalių, netradicinių ir natūralių produktų gamyba pagal senąsias tradicijas, patirties igijimas, verslumo žinių tobulinimas ir užimtumo didinimas.

Tautinio paveldo produktų verte padeda geriau suprasti tautinio paveldo produktų kūrèjų veiklą, per kurią yra plètojamas konkurencinis pranašumas ir sukuriama vertè ne tik šių produktų kūrèjams, bet ir vartotojams.

\section{TAUTINIO PAVELDO IŠSAUGOJIMAS IR PLÉTRA LIETUVOJE}

Globalizacijos procesai, kitų šalių kultūrų poveikis, nepakankama žinių apie tautos materialųji ir nematerialųji paveldą sklaida kelia nacionalinio tapatumo bei tautinio-kultūrinio paveldo išsaugojimo ir panaudojimo problemų grèsmę etninei kultūrai - niveliuojasi tradicijos ir papročiai, nyksta etnografinių regionų skirtumai (Ribašauskienè, 2008). Dèl eurointegracijos ir globalizacijos procesų Lietuvoje žemés ūkio veikla praranda ankstesnị mastą. Europos Sąjungos kaimo plètros

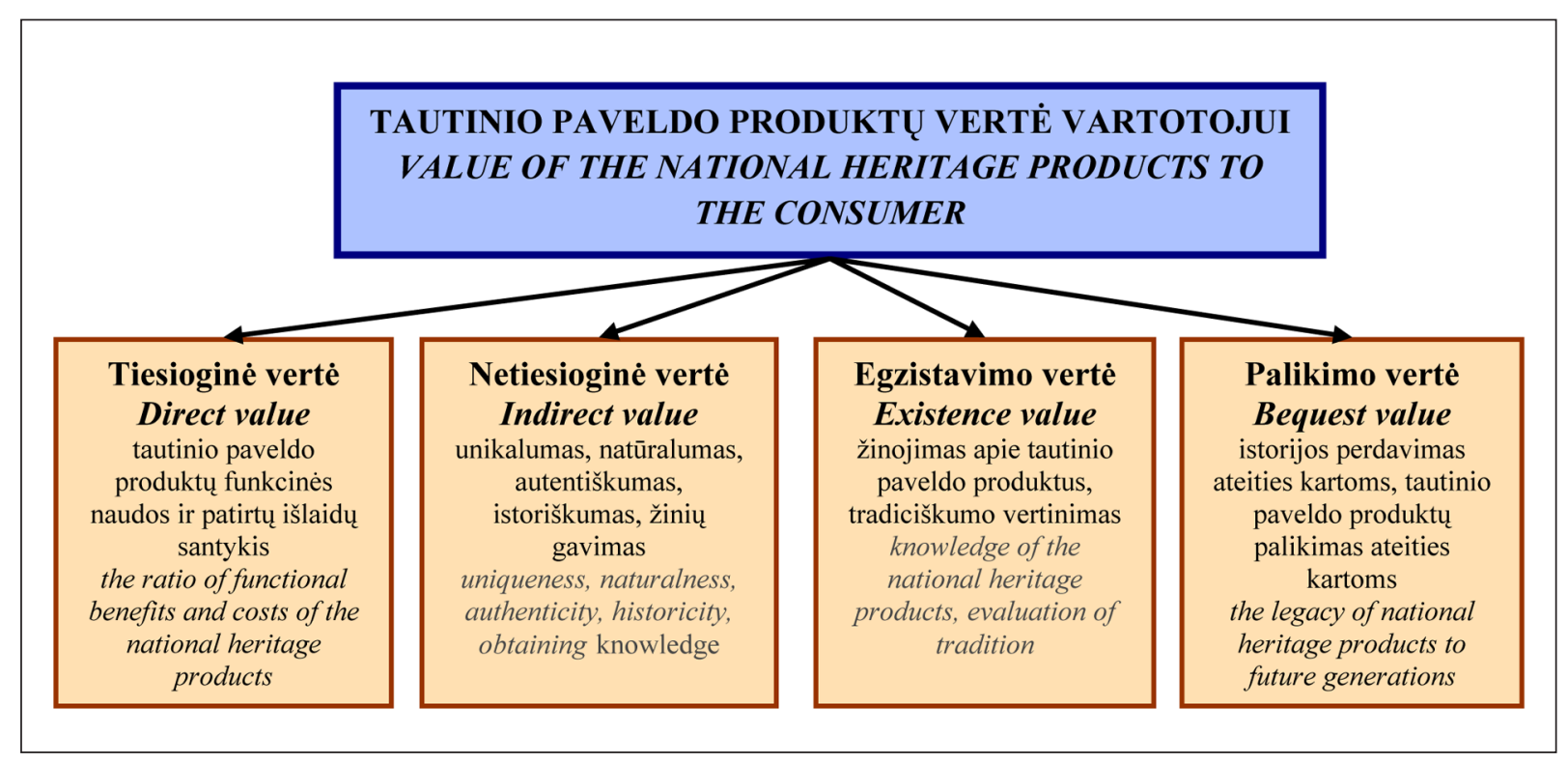

1 pav. Tautinio paveldo produktų vertè vartotojui

Fig. 1. Value of the national heritage products to the consumer 


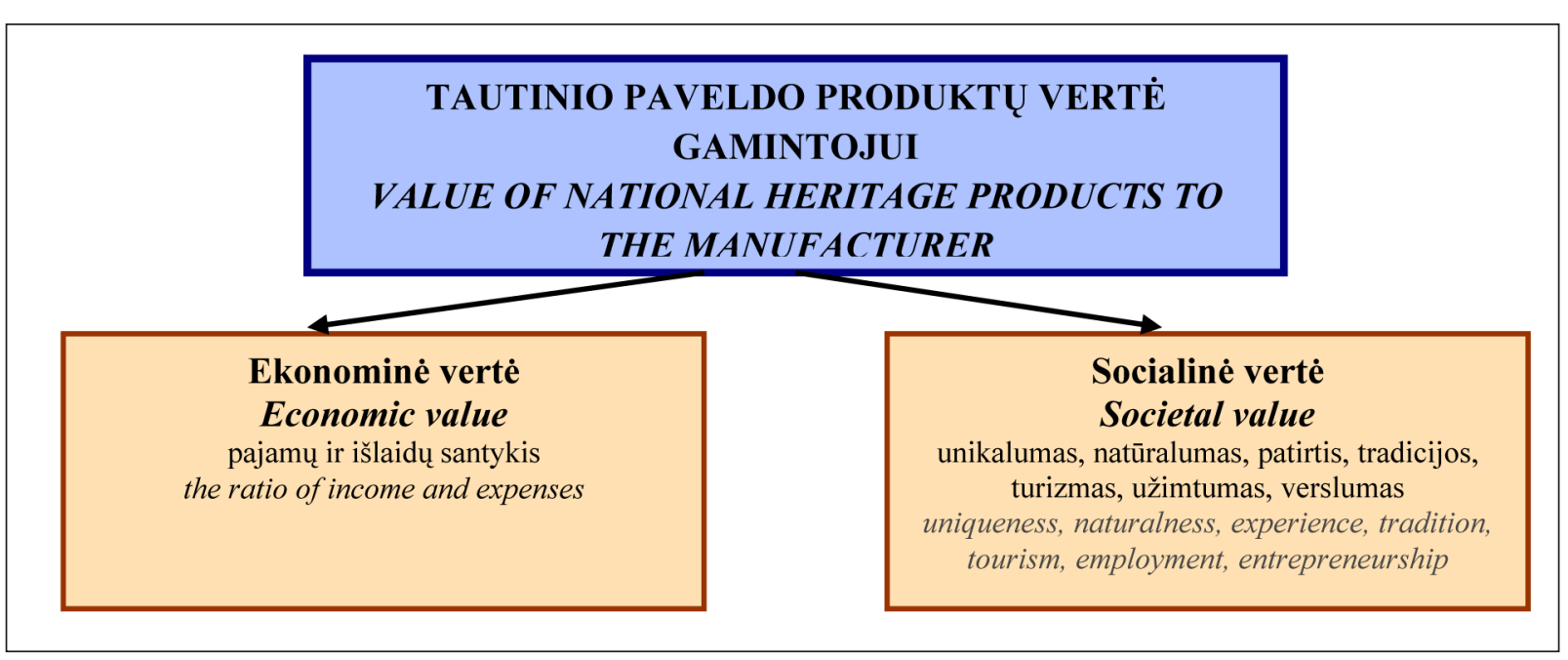

2 pav. Tautinio paveldo produktų vertė gamintojui

Fig. 2. Value of the national heritage products to the manufacturer

politika remia daugiafunkcinę žemès ūkio ir kaimo plètrą bei skiria didelį dèmesị kaimo vietovių konkurencingumui didinti panaudojant vietos išteklius. Tautinio paveldo produktai, kaip verslo atgaivinimo ir plètros įrankiai, gali pastebimai prisidèti prie kaimo gyventojų užimtumo ir kaimo konkurencingumo didinimo (Aleksandravičius, Atkočiūnienè, Raupeliené, 2008). Tautinio paveldo produktai - tai nustatyta tvarka sertifikuoti tradiciniai gaminiai, tradicinių veislių augalai ir gyvūnai bei jų produktai, tradicinès paslaugos, pasižyminčios istoriškai Lietuvoje ar jos atskirame etnografiniame regione susiformavusia produkto tradicine forma, sudetimi ir kitais specifiniais kokybiniais ypatumais ${ }^{1}$.

Siekdama valstybiniu mastu skatinti tradiciniu amatų veiklą, Lietuvos Respublikos Vyriausybė $2008 \mathrm{~m}$. liepos 16 d. nutarimu Nr. 775 patvirtino Ilgalaikę tautinio paveldo produktų išsaugojimo, populiarinimo, sukūrimo ir realizavimo skatinimo strategiją bei Tautinio paveldo produktų apsaugos, ju rinkos ir amatu plètros 2008-2015 m. programą. Lietuvos Respublikos Vyriausybè, igyvendindama Tautinio paveldo produktų įstatymo nuostatas, $2007 \mathrm{~m}$. spalio $2 \mathrm{~d}$. nutarimu igaliojo Žemès ūkio ministeriją nuo $2008 \mathrm{~m}$. sausio $1 \mathrm{~d}$. atlikti Tautinio paveldo produktų institucijos funkcijas ${ }^{2}$. Tautinio paveldo produktų valstybinę

LR Tautinio paveldo produktų ịstatymas. Nr. X-1207, 2007.

2 Tautinio paveldo produktų teisès aktai. Prieiga per internetą: http://www.tautinispaveldas.lt/portal/Pagrindinis/Teisesaktai/tabid/59/Default.aspx apsaugą užtikrinančių institucijų iniciatyva, tautinio paveldo produktų sertifikavimo procesas vyksta nuolat. Kiekvienais metais sertifikuojami nauji tautinio paveldo produktai, atitinkantys atitikties kriterijus. Daugiausiai tautinio paveldo produktų buvo sertifikuota $2010 \mathrm{~m}$. - net 496, iš kurių 334 ne maisto srities ir 162 maisto srities tautinio paveldo produktai (3 pav.). Tautinio paveldo produktų sertifikavimo dinamika rodo, kad ne maisto srities tautinio paveldo produktų yra sertifikuojama daugiau (iki $2011 \mathrm{~m}$. liepos 15 d. - 721) negu maisto srities tautinio paveldo produktų (per tą patị laikotarpi - 438).

Pagal sertifikuotų produktų skaičių, vienas iš populiariausių amatų yra maisto ruošimas (Tautinis paveldas, 2011) - sertifikuoti 137 tautinio paveldo produktai. Šiuo amatu užsiima 18 amatininkų, dirbančių 14 skirtingų Lietuvos teritorijų, daugiausia kaimiškose vietovèse. Dar vienas populiaresnių amatų pagal sertifikuotų produktų skaičiu yra audimas - sertifikuoti 29 amatininkų 106 tautinio paveldo produktai 14 skirtingų Lietuvos teritorijų. Populiarus drožybos amatas. Juo užsiima 22 asmenys, kurie yra sertifikavę 101 tautinio paveldo produktą. Tradicine drožyba užsiimama 16 skirtingų Lietuvos vietovių, daugiausia miestuose. Pats populiariausias amatas pagal amatininkų skaičių yra kepimas. Juo verčiasi net 37 šalies gyventojai, išsibarstę 30 skirtingų vietovių, ir yra sertifikavę 91 tautinio paveldo produktą. Tradicinis kepimas yra populiaresnis kaimiškose vietovèse. 


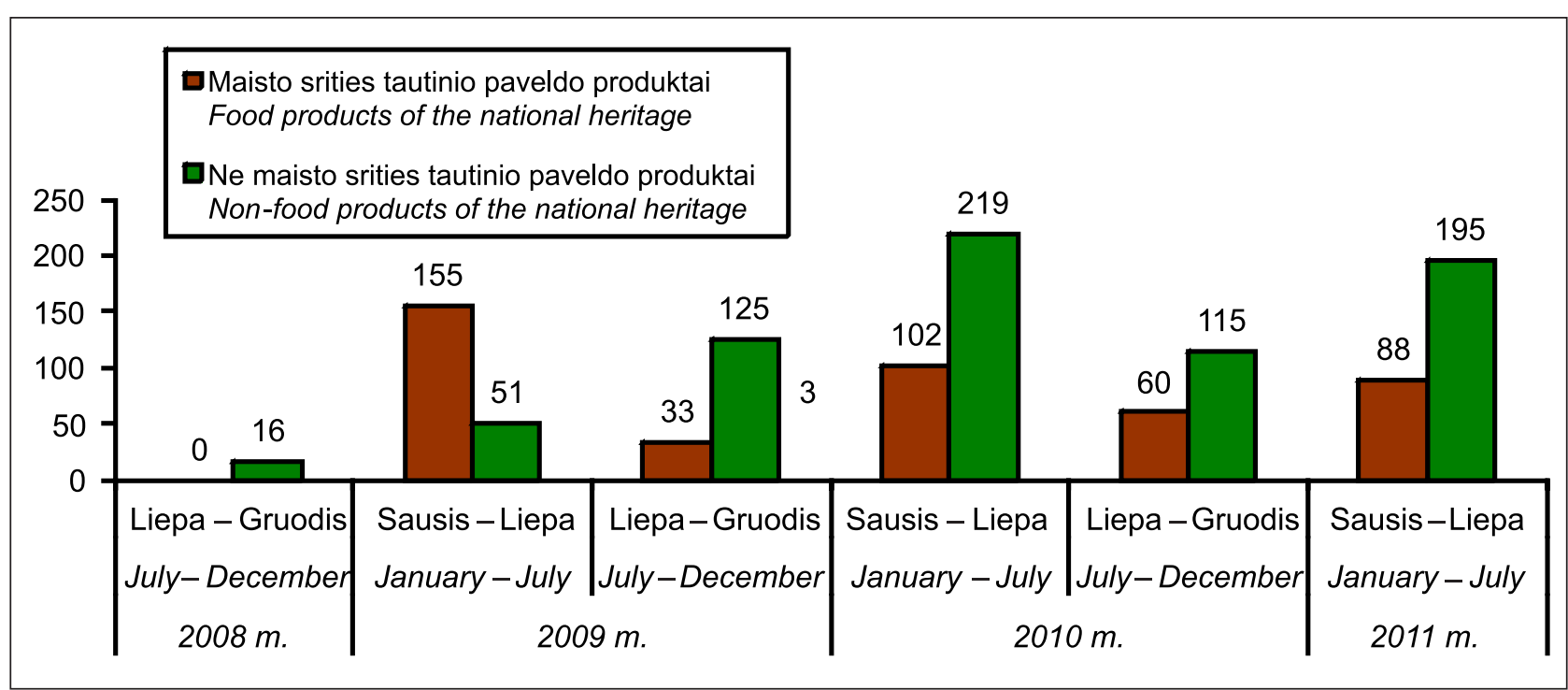

3 pav. Tautinio paveldo produktų sertifikavimas $2008 \mathrm{~m}$. spalio - $2011 \mathrm{~m}$. liepos mèn.

Fig. 3. National Heritage Product Certification in October 2008 - July 2011

Iš viso Lietuvoje yra sertifikuota 1159 tautinio paveldo produktų, o tradicine amatininkyste užsiima 353 amatininkai. Daugiausia jų yra Vilniaus mieste - net 58. 23 amatininkai, sertifikavę tautinio paveldo produktų, yra Kaune, 16 - Ukmergès r., 11 - Kretingos r., po 9 amatininkus yra Prienų ir Šiaulių r., 8 - Utenos $r^{3}$.

Tautinio paveldo produktų plètra yra aktuali ne tik saugant šimtametes šalies tradicijas, bet ir keliant šalies ekonomikos lygi, mažinant netolygumus tarp Lietuvos regionų bei gerinant Lietuvos miestelių, kaimų bei probleminių Lietuvos teritorijų ekonominę padetį. Tautinio paveldo produktai atskleidžia ir populiarina Lietuvos istoriją, tradicijas bei kultūrą visame pasaulyje, nes tautinio paveldo produktų gamintojai aktyviai dalyvauja tarptautinèse parodose, mugèse bei kituose renginiuose. Lietuvos tautinio paveldo produktai sulaukè didelio susidoméjimo Ventspilyje vykusiame tarptautiniame amatininku forume, Rygoje tarptautineje parodoje Rigafood, Kaziuko mugèje Dubline, Maskvoje vykusioje tarptautinèje parodoje Zolotaja osenj ir kt.

3 LR Žemès ūkio ministro ịsakymas $2011 \mathrm{~m}$. liepos $14 \mathrm{~d}$. Nr. 3D-577 Dèl Žemès ūkio ministro $2008 \mathrm{~m}$. spalio 24 d. Nr. 3D-562 „Dél tautinio paveldo produktu, tradicinių amatų meistru ir tradiciniu amatų mokymo programų sąrašų patvirtinimo" pakeitimo.

\section{EMPIRINIO TYRIMO REZULTATAI IR JŲ APTARIMAS}

\section{Hipotezès „Tautinio paveldo produktu gamintojai taiko tradicines (nusistovèjusias) rinkodaros priemones" tikrinimas}

Ši hipotezè tiriama siekiant nustatyti taikomas rinkodaros priemones, tautinio paveldo produktuc gamintojų charakteristikas, tautinio paveldo produktų realizavimo vietas, vartotojų pritraukimo būdus. Pagal iš anksto sudarytą klausimyną buvo apklausti 22 tautinio paveldo produktų gamintojai.

Tyrimas parode, kad vidutinis tautinio paveldo produktų gamintojas yra 54 metų, gyvenantis kaimiškoje vietoveje, dirbantis pagal verslo liudijimą ir meno kūrèjo statusą. Verslo puoselèjimui ES parama nesinaudoja.

Tyrimo metu nustatyta, jog gamintojai, parduodami savo sertifikuotus tradicinius gaminius, taiko jiems priimtiniausius metodus: vieni pardavineja parodose ir mugèse, kiti - tiesiai iš tautodailininku dirbtuvių arba iš namų, nuosavų amatų galerijų, kuriuose dirba, prekiauja tarptautinèse parodose, ùkininkų turgeliuose ir mobiliuosiuose turgeliuose ir tik maža dalis $(6,7 \%)$ apklaustųjų savo gaminiais prekiauja elektroninèje erdvèje (4 pav.).

Tyrimo metu buvo siekiama sužinoti, ar tautinio paveldo produktų kūrèjai norètų, jog jų sertifikuotais tradiciniais gaminiais būtų prekiaujama 


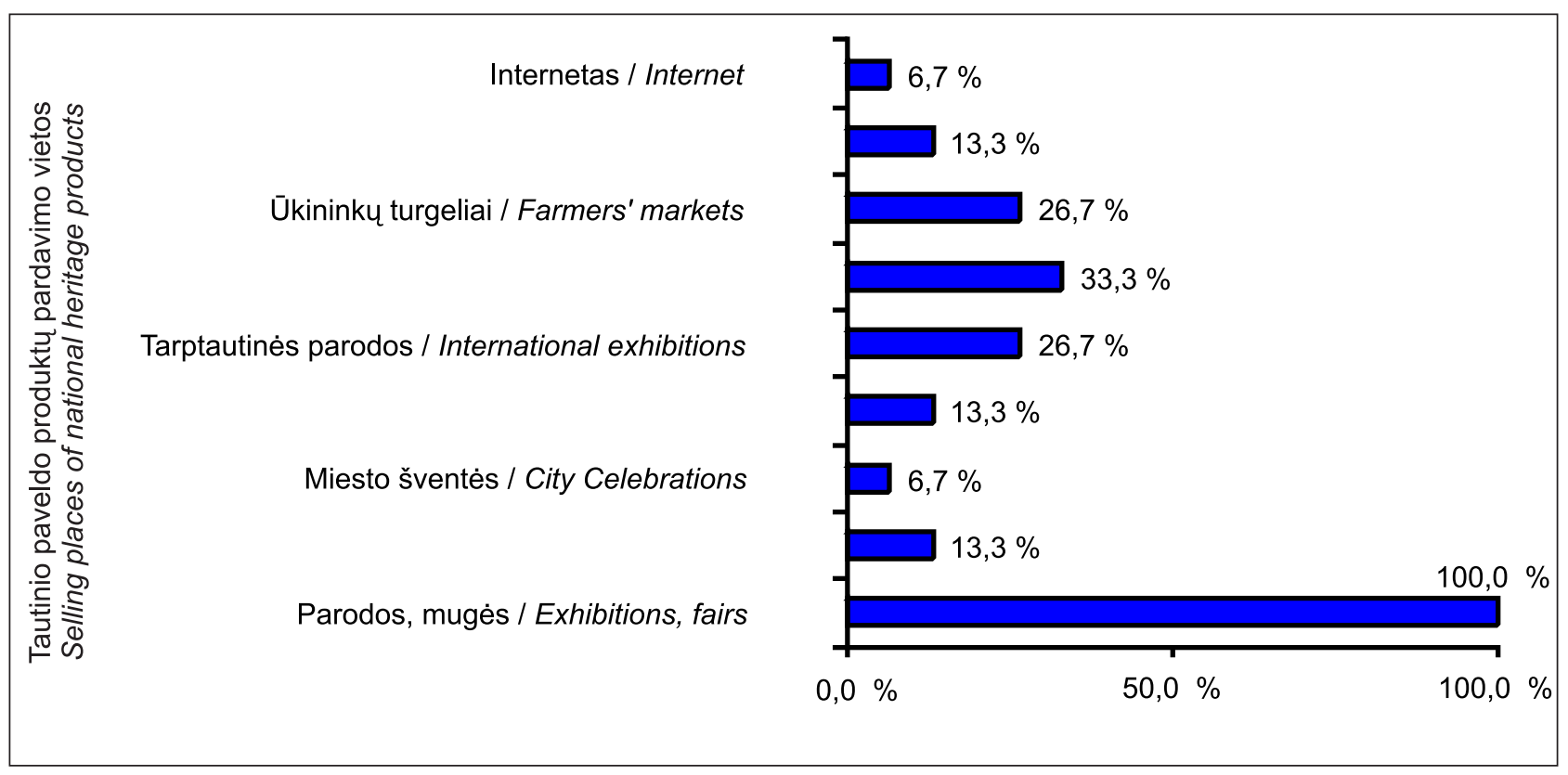

4 pav. Tautinio paveldo produktų gamintojų pasirenkamos pardavimo vietos $\%$

Fig. 4. Selling places selected by manufacturers of national heritage products, $\%$

didžiuosiuose Lietuvos prekybos centruose. $\mathrm{Nu}$ statyta, kad amatininkai, kurie gamina sertifikuotus tradicinių amatų gaminius, nenori, kad jų sertifikuotais produktais būtų prekiaujama kartu su masinès gamybos produktais. Tačiau maisto srities tautinio paveldo produktų gamintojai nebūtų priešiškai nusiteikę prieš prekybą didžiuosiuose prekybos centruose, tik pabrèžia, jog turètų būti įrengti specialūs stendai, atspindintys produktų unikalumą.

Tyrimo metu buvo siekiama išsiaiškinti, kokias rèmimo priemones amatininkai naudoja, kad pritrauktų didesnị vartotojų dèmesị. Nustatyta, kad kai kurie turi ịkūrę savo tradicinių gaminių muziejus, priima ekskursijas ir tokiu būdu reklamuoja savo amatą, kiti reklamuojasi vietiniuose laikraščiuose, dar kiti - ịvairiose liaudies darbų ir meno parodose, mugèse. Tik apie $20 \%$ respondentų turi susikūrę internetines svetaines. Respondentu pasiskirstymas pagal naudojamas rèmimo priemones pateikiamas 5 pav.

Didžioji respondentų dalis mano, kad siekiant didinti paklausą būtina sutelkti dèmesị $\mathfrak{t}$ informacijos sklaidą. 33,3 \% respondentų siūlo įsteigti specializuotas parduotuvèles, kuriose būtų prekiaujama tik tautinio paveldo produktais, o jas steigti ten, kur yra didžiausi turistų srautai.
$13,3 \%$ respondentų siūlo organizuoti daugiau renginių, miesto švenčių, parodų ir mugių turistinese vietose ir reklamuoti sertifikuotus produktus per televiziją bei radiją.

Kaip parodè tyrimas, kol kas daugelis amatininkų taiko tradicines rinkodaros priemones, neskirdami reikiamo dèmesio jų perkèlimui į elektroninę erdvę.

\section{Hipotezès „Tautinio paveldo produktų paklausa priklauso nuo jų realizavimo vietų" tikrinimas}

Tyrimo metu buvo siekiama sužinoti, ar vartotojai atkreipia dèmesi i nio paveldo produktų ženklu. Nustatyta, kad $52 \%$ respondentų neatkreipia ì juos dèmesio. Galima daryti išvadą, jog tautinio paveldo produktų ženklai (A ir B kategorijos) nèra labai populiarūs, ju negalima laikyti tautinio paveldo produktų prekiniu ženklu. Taip pat nustatyta, kad 52,7 \% respondentų tautinio paveldo produktų niekada nebuvo pirkę, o tai rodo, kad jų paklausa yra pakankamai mažai.

Tačiau siekiant sužinoti, kokie tautinio paveldo produktai (maisto ar ne maisto) yra patys paklausiausi, respondentų, kurie buvo issigiję šių gaminių, buvo klausiama, kokius gaminius jie yra 


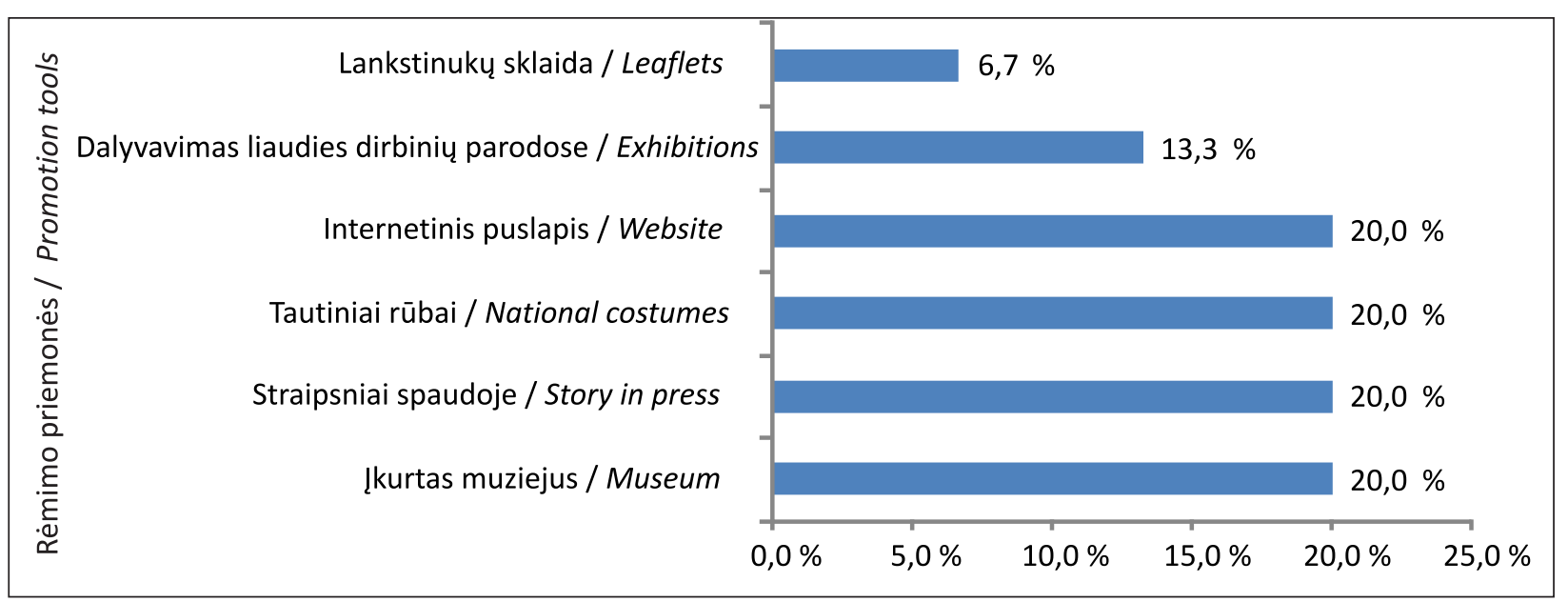

5 pav. Tautinio paveldo produktų gamintojų naudojamos rèmimo priemonès $\%$

Fig. 5. Promotion tools, \%

(buvo) pirkę. Nustatyta, kad didžiausia paklausa yra maisto rūšies tautinio paveldo produktų (juos pasirinko $66,2 \%$ respondentų), tačiau 50,7 \% respondentų yra (buvo) ísigiję ir ne maisto rūšies tautinio paveldo produktų. Pati prieinamiausia tautinio paveldo produktų pardavimo vieta yra mugès, ịvairiausios parodos ir amatininkų dirbtuvès (6 pav.).

Siekiant padidinti tautinio paveldo produktų paklausą, svarbu išsiaiškinti priežastis, kodèl vartotojai neperka sertifikuotų tradicinių gaminių. Nustatyta, kad 48,1 \% respondentų nèra pirkę tau- tinio paveldo produktų, nes nežino, kur jų galima issigyti. 46,8 \% respondentų prekes ir gaminius perka tik iš prekybos centrų, o juose tautinio paveldo produktų neranda, $38 \%$ pirkejjų nèra jokio skirtumo, ar pirkti sertifikuotą produktą, ar ne. $26,6 \%$ respondentų nèra priimtina tautinio paveldo produktų kaina, o 12,7 \% apklaustųjų tautinio paveldo produktų neperka dèl kitų priežasčių, kurių nenurodè (7 pav.).

Galima daryti išvadą, kad pagrindinè priežastis, kuri mažina tautinio paveldo produktų paklausą, yra per maža informacijos skaida apie tautinio paveldo

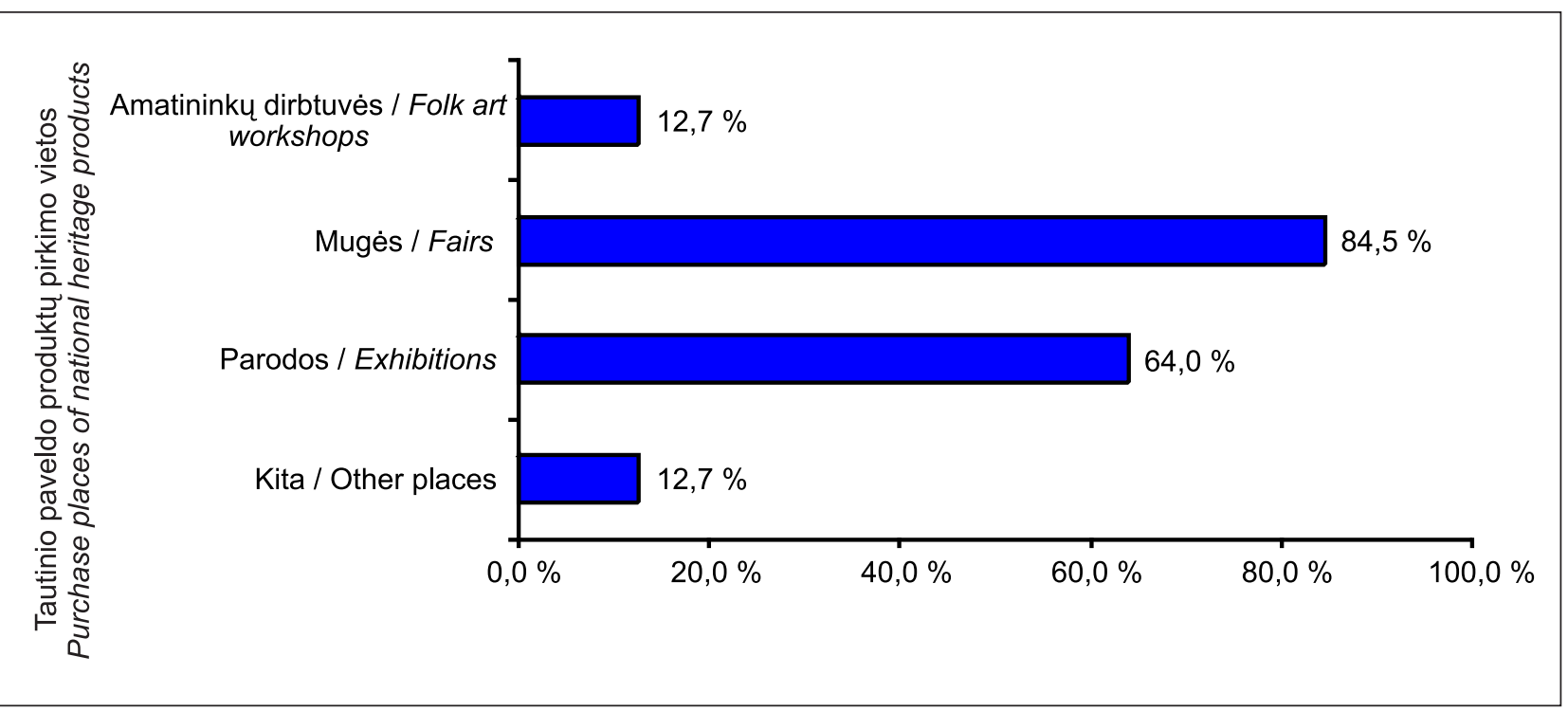

6 pav. Respondentų pasiskirstymas pagal tautinio paveldo produktų pirkimo vietas \% Fig. 6. Distribution of respondents according to the purchase places of national heritage products, \% 
produktų pardavimo vietas. Tačiau tyrimo metu nustatyta, kad jeigu tautinio paveldo produktai būtu pigesni ir jais prekiaujama prieinamose vietose (taip pat ir virtualiose parduotuvese), tai ju paklausa būtų kur kas didesnè.

\section{Hipotezès „Tautinio paveldo produktų kūrèjų veikla natūraliai formuoja amatininkų centrus“ tikrinimas}

Atliekant tautinio paveldo produktų sertifikavimo statistinę duomenų analizę, suskaičiuoti įvairiose vietovèse gyvenantys tautinio paveldo produktų kūrẻjai, pateikti vidurkiai, kiek vidutiniškai jų (amatininkų) tenka 100000 vietos gyventojų (1 lentelè). Siekiant užtikrinti tyrimo rezultatų patikimumą, analizè buvo vykdoma ịvairiais pjūviais (1 lentelè).

Agreguoti duomenys skaičiuoti pagal Tautinio paveldo 2011 ir Lietuvos Statistikos departamento 2011 informaciją.

Išanalizavus ir susisteminus tautinio paveldo produktų sertifikavimo statistikos duomenis bei apskaičiavus vidutini amatininkų skaičiu ịvairiose vietovèse (1 lentelè), duomenys suskirstyti $\mathfrak{i} 3$ grupes: A - vidutinio dydžio miestai ir didieji miestai su priemiestiniais rajonais (vidutinio dydžio be priemiestinių rajonų); $\mathrm{B}$ - kaimiškieji rajonai; C - miesteliai.
Gauti rezultatai parodè, kad šių grupių vidurkių skirtumai yra maži (kepejuc $F$ kriterijaus reikšmè lygi 0,921 , stebimasis reikšmingumo lygmuo $p=0,401$; kryždirbių $F=0,374, p=0,689$; drožèjų $F=0,893$, $p=0,413$; iš viso amatininkų $F=1,835, p=0,165$ ). Atskiru grupių palyginimas parodè, kad nors su $5 \%$ reikšmingumo lygmeniu gauti vidurkių skirtumai yra nereikšmingi, didžiausi skirtumai yra bendro amatininkų skaičiaus tarp A ir C grupių (vidurkių skirtumas - 10,19, LSD kriterijaus stebimasis reikšmingumo lygmuo $p=0,074$ ) ir tarp A ir B grupiu (vidurkių skirtumas $-9,74, p=0,08$ ). Todèl buvo sujungtos $\mathrm{B}$ ir $\mathrm{C}$ grupès ir sudarytos dvi grupès:

I grupe - dešimt didžiausių Lietuvos miestų (remiantis 2011 metų surašymo duomenimis). I šią grupę ịtraukti ir penkių didžiausių miestų (Vilniaus, Kauno, Klaipedos, Šiaulių ir Panevéžio) priemiestiniai rajonai, kurie praplečia miestų ribas, atlikdami šių miestų priemiesčių funkcijas (Burinskienè, Rudzkienė, 2007). Kitu penkių mažesnių miestų (Alytaus, Marijampolès, Mažeikių, Jonavos ir Utenos) ittaka priemiestiniams rajonams nèra ryški, todèl šių miestų priemiestiniai rajonai ì šią grupę neįtraukti. II grupe - maži miesteliai kartu su kaimiškaisiais rajonais. Grupès skirtingu dydžių: pirmają grupę sudaro 15 miestų ir priemiestinių rajonų, antrąą - 87 miesteliai ir kaimiškieji rajonai.

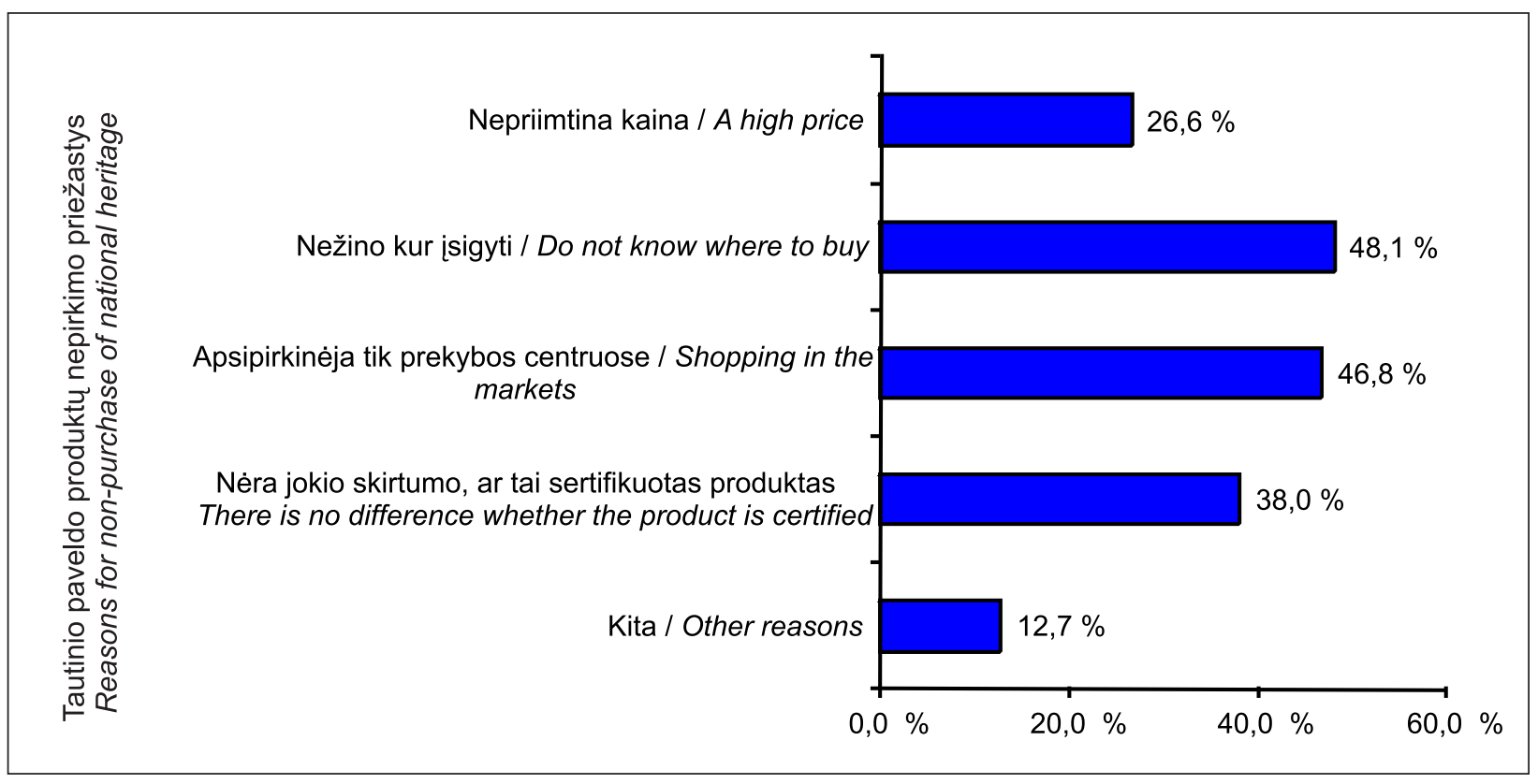

7 pav. Priežastys, trukdančios įsigyti tautinio paveldo produktų, $\%$

Fig. 7. The reasons that hinder the acquisition of national heritage products, $\%$ 
1 lentelè. Ivairiose vietovėse gyvenančių tautinio paveldo produktų gamintojų skaičius, tenkantis 100000 gyventojų Table 1. National heritage producers in different areas, per 100000 population

\begin{tabular}{|c|c|c|c|c|}
\hline Vietovè / Locality & 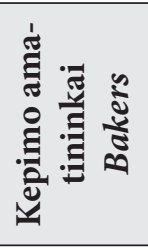 & 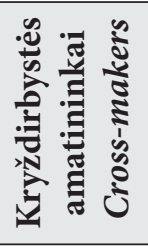 & 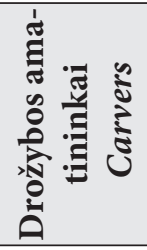 & 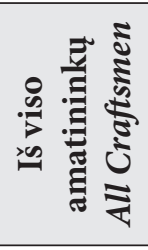 \\
\hline Lietuva / Lithuania & 1,2 & 0,6 & 0,7 & 10,7 \\
\hline Didieji miestai / Major cities & 0,2 & 0,1 & 0,2 & 7,2 \\
\hline Vidutiniai miestai / Medium-size cities & 0,5 & 0,9 & 0,0 & 3,8 \\
\hline Mažieji miestai / Small cities & 2,4 & 1,0 & 1,0 & 6,9 \\
\hline Kaimai / Villages & 2,0 & 0,9 & 0,9 & 13,0 \\
\hline Probleminès teritorijos / Problem areas & 1,1 & 1,1 & 0,9 & 9,4 \\
\hline \multicolumn{5}{|l|}{ Nacionaliniai parkai: / National parks: } \\
\hline 1. Aukštaitijos & 1,0 & 0,0 & 1,0 & 14,9 \\
\hline 2. Žemaitijos & 2,4 & 0,0 & 2,4 & 14,3 \\
\hline 3. Dzūkijos & 0,7 & 0,7 & 1,38 & 12,5 \\
\hline 4. Kuršių nerijos & 0,0 & 0,0 & 0,0 & 0,0 \\
\hline \multicolumn{5}{|l|}{ Etnografiniai regionai: / Ethnographical regions: } \\
\hline 1. Aukštaitija & 1,8 & 1,0 & 0,2 & 14,0 \\
\hline 2. Dzūkija & 0,7 & 0,2 & 0,9 & 11,0 \\
\hline 3. Žemaitija & 1,3 & 0,8 & 0,8 & 8,6 \\
\hline 4. Suvalkija & 0,3 & 0,5 & 0,9 & 9,7 \\
\hline
\end{tabular}

Šių grupių vidurkių lygybė buvo tikrinama Stjudento $t$ kriterijumi. Buvo nustatyta, kad bendras vidutinis amatininkų skaičius reikšmingai skiriasi $(t=4,032 ; p=0,00015)$. Miesteliuose ir kaimuose vidutiniškai gyvena 15,6 amatininko 100000 gyventojų, vidutinio dydžio ir didžiuosiuose miestuose su priemiestiniais rajonais - 5,6. Taigi galima daryti išvadą, kad tautinio paveldo produktų gamyba yra mažų miestelių ir kaimiškų vietovių alternatyvi žemès ūkiui veikla, kuri kelia šalies mažų miestų ir kaimo vietovių lygit, skatina užimtumą ir mažina skirtumus tarp regionų.

Buvo tikrinama dar kelios hipotezès. Pirmoji - kad ịvairių amatų rūšių amatininkų skaičius Lietuvos etnografiniuose regionuose vienodas. Ši hipotezè pasitvirtino (didžiausi skirtumai nustatyti amatininkų atveju: $F=1,25, p=0,266)$, t. y. galima teigti, kad tautinio paveldo produktų kūrejjai etnografiniuose regionuose yra pasiskirstę tolygiai.

Antroji hipotezè - kad ịvairių amatų rūšių amatininkų skaičius Lietuvos probleminèse ir ne probleminèse teritorijose vienodas. Šios hipotezès atmesti nepavyko (didžiausi skirtumai nustatyti amatininkų atveju: $F=2,79, p=0,171$ ), todèl galima teigti, kad tautinio paveldo produktų kūrejjų skaičiaus skirtumų tarp probleminių teritorijų ir neprobleminių teritorijų nèra.

Paskutiné, trečioji, hipotezè, kad saugomos teritorijos tampa nacionalinio paveldo centrais. Stjudento $t$ kriterijumi buvo tikrinama hipotezè, kad i nacionalinių parkų teritorijas įeinančiuose rajonuose vidutiniškai gyvena tiek pat amatininku kaip ir kitose Lietuvos teritorijose. Rezultatai parode, kad vidurkiai nesiskiria beveik visais atvejais, išskyrus kryždirbystès. Kryždirbių nacionalinių parkų rajonuose gyvena beveik 10 kartų mažiau nei kituose rajonuose (vidurkių skirtumas 9,78, $F=7,79, p=0,003$ ). Visais kitais atvejais skirtumai nereikšmingi (kepejų: $t=0,636, p=0,526$; iš viso amatininkų: $t=-0,189, p=0,851$; drožejų: $t=-0,152, p=0,880)$.

\section{IŠVADOS}

1. Tautinio paveldo produktų koncepcija yra orientuota $\mathfrak{i}$ istoriškai susiformavusių tradicijų ir perduodamos patirties bei igūdžių puoselèjimo, išsaugojimo, realizavimo ir populiarinimo būdu visumą. Jos igyvendinimą reglamentuoja sukurta teisinè bazé, užtikrinanti tautinio paveldo produk- 
tų valstybinę apsaugą. Iš viso Lietuvoje yra 66 istoriškai susiformavę tradiciniai amatai, sertifikuota 1159 tautinio paveldo produktų, o tradicine amatininkyste užsiima 353 amatininkai.

2. Tautinio paveldo produktų plètra yra naudinga ne tik saugant šimtametes tradicijas, bet ir keliant valstybès ekonomikos lygi, mažinant netolygumus tarp Lietuvos regionų bei gerinant Lietuvos miestelių, kaimų bei probleminių Lietuvos teritorijų ekonominę padetit.

3. Atliktas tautinio paveldo produktų kūrèjų veiklos tyrimas patvirtino hipotezę, kad kol kas daugelis amatininku taiko tradicines rinkodaros priemones, neskirdami reikiamo demesio rinkodaros inovacijoms ir perkèlimui į elektroninę erdvę. Tik apie $20 \%$ respondentų turi susikūrę interneto svetaines.

4. Tautinio paveldo produktų vertès ir poreikio vartoti tyrimas patvirtino hipotezę, kad tautinio paveldo produktų paklausa ir vertė vartotojui priklauso nuo patrauklių ir prieinamų pardavimo vietų. Nustatyta, kad tautinio paveldo produktų paklausa yra per maža, nes nèra sukurta nuolatinių prekybos vietų, o per maža informacijos sklaida neskatina vartotojų domètis tradiciniais gaminiais.

5. Atliktas keturių pjūviu tautinio paveldo produktų plètros tyrimas atskleide, kad tautinio paveldo produktų kūrejjų veikla ịvairiose vietovèse natūraliai neformuoja amatų centrų kūrimosi, nes didelių skirtumų tarp amatininkų skaičiaus nacionaliniuose parkuose, etnografiniuose regionuose, probleminèse Lietuvos teritorijose ir didžiuosiuose, vidutiniuose miestuose ir miesteliuose beveik nèra, išskyrus kaimiškąsias vietoves. Todèl amatų centrų kūrimosi vietas tikslinga orientuoti ne $\mathfrak{i}$ vietoves, kur yra didžiausias ar mažiausias gamintojų skaičius, bet ten, kur yra intensyviausi turistų srautai.

6. Remiantis atliktų trijų tipų empirinio tyrimo rezultatų analize, greta tautinio paveldo produktų gamintojų naudojamų tradicinių (nusistovejusių) rinkodaros priemonių, siūlomi alternatyvūs tautinio paveldo produktų paklausos ir vertès didinimo sprendimai: 1) tautinio paveldo produktu mokslinių etimologinių tyrimų vykdymas; 2) informacinių technologijų taikymas tautinio paveldo produktams populiarinti elektroninejje erdveje; 3) tautinio paveldo produktų pozicionavimo programos sukūrimas.

\section{PADE்KA}

Pirmosios autorès tyrimas atliktas vykdant Lietuvos mokslo tarybos remiamą projektą MIP11115 „Saugomų ekosistemų vertinimas socialiniu-ekologiniu aspektu“".

Autorès dèkoja anoniminiams recenzentams už vertingas pastabas, padejusias praturtinti straipsni naudinga informacija.

Gauta 20120210

Priimta 20120327

\section{LITERATŪRA}

1. Aleksandravičius A., Atkočiūnienè V., Raupelienè A. 2008. Tautinio paveldo produktų išsaugojimo ir gamybos plètros svarba kaimo darniai plètrai. Ekonomika ir vadyba: aktualijos ir perspektyvos. Nr. 2(11). P. 228-233.

2. Aleksandravičius A., Klupšas F. 2009. Tradicinių amatų išsaugojimo ir jų plètros svarba kaimo darniam vystymuisi. Vadybos mokslas ir studijos - kaimo verslu ir ju infrastruktūros plètrai. Nr. 19(4). P. 6-14.

3. Atkočiūnienè V., Aleksandravičius A., Albrektaitė D. 2008. Tradicinių amatų situacija Lietuvoje ir jų plètros galimybès. Vadybos mokslas ir studijos - kaimo verslu ir ju infrastruktūros pletrai. Nr. 12(1). P. 24-33.

4. Bateman I. et al. 2002. Economic Valuation with Stated Preferences Techniques: a Manual. Cheltenham. UK: Edward Elgar.

5. Burinskienė M., Rudzkienè V. 2009. Future Insights, Scenarios and Expert Method Application in Sustainable Territorial Planning. Technological and Economic Development of Economy. Baltic Journal on Sustainability. Vilnius: Technika. Nr. 15(1). P. 10-25.

6. Burinskienè M., Rudzkienè V. 2007. Variability and the relationship between quality of life and real estate prices in Lithuania. International Journal of Environment and Pollution (IJEP). Vol. 30. No.3-4. P. 501-517.

7. Brytting T., Trollestad C. 2000. Managerial Thinking on Value-Based Management. International Journal of Value-Based Management. Vol. 13. No. 1. P. 55-77.

8. Freeman A. M. 1993. The Measurement of Environmental and Resource Values. Theory and Methods. Resources for the Future. Washington DC.

9. Haksever C. et al. 2004. A Model of Value Creation: Strategic View. Journal of Business Ethics. Vol. 49. No. 3. P. 291-305. 
10. Jasaitis J. 2008. Šiuolaikinio lietuviškojo kaimo vizijos kūrimas. Ekonomika ir vadyba: aktualijos ir perspektyvos. Nr. 2(11). P. 15-27.

11. Jasaitis J., Kriaučiūnienè V. 2010. Alternatyvios veiklos plètra kaimiškose vietovèse. Ekonomika ir vadyba: aktualijos ir perspektyvos. Nr. 3(19). P. 7584.

12. Michael E. Porter, Mark R. Kramer. 2011. Creating Shared Value. Harvard Business Review. JanuaryFebruary.

13. Neap H. S., Celik T. 1999. Value of a Product: A Definition. International Journal of Value-Based Management. Vol. 12. No. 2. P. 181-191.

14. Ribašauskienè E. 2008. Tradiciniai amatai Lietuvoje: situacija ir perspektyvos. Rinkotyra. Žemès ūkio maisto produktai. Nr. 4(42). P. 91-99.

15. Rosalind C. Paige, Mary A. Littrell. 2002. Craft Retailers Criteria for Success and Associated Business Strategies. Journal of Small Business Management. Vol. 40(4). P. 314-331.

16. Siemieniako et al. 2011. National and Regional Ethnocentrism: a Case Study of Beer Consumers in Poland. British Food Journal. Vol. 113. No. 3. P. 404-418.

17. Susan J. Terrio. 2008. Performing Craft for Heritage Tourists in Southwest France. Journal of City \& Society. JUN.

18. Taito group. Handicraft Services - Culture, Skill [žiūrèta 2011-12-12]. Prieiga per internetą: http:// www.taito.fi/en/services/handicraft-services-culture-skill/

19. Tautinis paveldas [žiūrèta 2011-09-27]. Prieiga per internetą: http://www.tautinispaveldas.lt/zemelapis/

20. Tumėnas V. 2010. Tautinio paveldo produktų ịstatymo igyvendinimo problemos. Konferencija „Lietuvos tautinis paveldas: dabartis ir perspektyvos".

21. Xianghong F. 2008. Gender and Hmong Women's Handicrafts in Fenghuang's. "Tourism Great Leap Forward", China. Journal of Anthropology of Work Review. JUN. Vol. 28. No. 3. P. 17-26.

\section{Vitalija Rudzkienė, Reda Skrodenytė}

\section{VALUE, MARKETING AND DEVELOPMENT TRENDS OF NATIONAL HERITAGE PRODUCTS}

\section{Summary}

National heritage, traditional crafts and culinary heritage are an important part of domestic ethnic culture. However, development of a system for reservation, promotion and sales of national heritage products requires more attention to marketing tools. Craftsmen, national security institutions as well as consumers are involved in the process of marketing strategy development. Manufacturers of national heritage products strive to make their products marketable, interesting to consumers and purchasable. The objective of national security institutions is to ensure preservation of national heritage products, promotion of production thereof, and development of traditional crafts. In order to achieve this objective, it is essential to apply proper measures for increasing the value of national heritage products and their demand.

Empirical research of three types was conducted in 20102011 at the Mykolas Romeris University. The purpose of the research was to analyze and evaluate the market of national heritage products in different areas of Lithuania from manufacturer and consumer's viewpoints. The following methods of research were used: Analysis of Variance (ANOVA), a questionnaire method and semi-structured interviewing.

An analysis of the significance of national heritage product development for domestic economy allows to determine that handicraft production and traditional product commerce are an economic, social, and cultural leverage for the majority of the world, thanks to which countries may prosper while preserving their identity in a globalised world.

There are 66 historically developed traditional crafts in Lithuania; 1,119 national heritage products are certified; 353 craftsmen are involved in traditional craftsmanship. The implemented study shows that production and development of national heritage products are beneficial not only in preserving domestic centuries-old traditions, but also in raising the country's level of economics, reducing inequalities among Lithuanian regions, and improving the economic situation of Lithuanian towns, villages and problematic areas. Activities of national heritage product developers in various areas cannot normally influence the creation of craft centres, thus, in order to enhance the value and demand for national heritage products, it is necessary to apply proper marketing tools which could help to increase their demand.

Analysis of the value and consumption demand for national heritage products has shown that the demand is too low because there are no regular trade places; therefore, consumers are not aware where to buy traditional certified products. Inadequate distribution of information about certified traditional goods, craftsmen and festivals inhibits consumers from taking interest in traditional crafts. However, a greater emphasis on marketing and application of its tools in national heritage product activities would allow consumers to notice signs of authenticity and uniqueness of these products and to enhance their demand.

Key words: national heritage products, national heritage product development, value of national heritage products, demand for national heritage products 